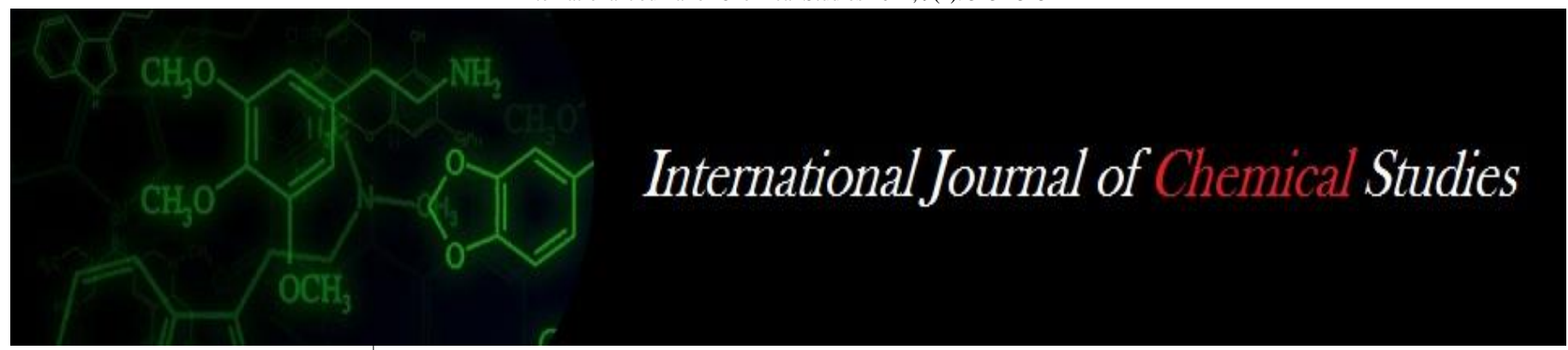

P-ISSN: 2349-8528

E-ISSN: 2321-4902

www.chemijournal.com

IJCS 2021; 9(1): 3432-3434

(C) 2021 IJCS

Received: 16-10-2020

Accepted: 27-12-2020

Som Prakash

Department of Vegetable

Science, College of Horticulture and Forestry, Narendra Deva

University of Agriculture and

Technology, Kumarganj,

Faizabad, Ayodhya, Uttar

Pradesh, India

\section{VP Pandey}

Professor, Department of

Vegetable Science, College of

Horticulture and Forestry,

Narendra Deva University of

Agriculture and Technology,

Kumarganj, Faizabad, Ayodhya,

Uttar Pradesh, India

Amit Kumar Bhargava

Department of Vegetable

Science, College of Horticulture

and Forestry, Narendra Deva

University of Agriculture and

Technology, Kumarganj,

Faizabad, Ayodhya, Uttar

Pradesh, India

\section{Assessment of correlation and path analysis in fenugreek (Trigonella foenum-graecum $\mathrm{L}$.) Germplasms}

\author{
Som Prakash, VP Pandey and Amit Kumar Bhargava
}

DOI: https://doi.org/10.22271/chemi.2021.v9.i1av.11767

\begin{abstract}
The present experiment was carried out "Assessment of correlation and path analysis in fenugreek (Trigonella foenum-graecum L.) Germplasms" during Rabi season of the year 2014-2015 at Main Experiment Station of Department of Vegetable Science (Vegetable Research Farm) at Narendra Deva University of Agriculture and Technology, Narendra Nagar (Kumarganj), Faizabad (Ayodhya) Uttar Pradesh, India. Seeds yield per plant showed that positive and highly significant correaltion association with pods per plant followed by length of pod whereas it showed highly negative correlation significant seeds per pod followed by 1000 -seed weight at genotypic and 1000-seed weight followed by days to $50 \%$ flowering at phenotypic correlation coefficient. Path analysis carried out at genotypic as well as phenotypic level revealed that was exerted by pods per plant followed by length of pod had positive direct effect on seed yield per plant, this indicates that selection for these traits will be useful.
\end{abstract}

Keywords: Fenugreek, correlation coefficient and path analysis

\section{Introduction}

Fenugreek (Trigonella foenum- graecum) belongs to family Fabaceae, $2 \mathrm{n}=16$. It is seed spice as well as leafy vegetable. It has been originated in Egypt. Fenugreek can be grown in the tropical and in temperate regions. It is grown from sea level up to an altitude of $2000 \mathrm{~m}$. There are two species of the genus Trigonella, which are of economic importance, viz., Trigonella foenumgraecum or the commonly called "methi" and Trigonella corniculata or the "kasthuri methi." Fenugreek is an annual herb, 30 to $90 \mathrm{~cm}$ tall and has light green leaves which are pinnately trifoliate. The flowers are papillonaceaus and white or yellow in colour and produces stander, beaked pods of approximately 10-15 cm long and each pod contains 10-20 small hard yellowish brown seed possessing smooth and oblong, about $3 \mathrm{~mm}$ long, each grooved across one corner, giving them a hooked appearance. India is also known as land of spices. However, in India it is mainly grown in Rajasthan, Madhya Pradesh, Uttar Pradesh and Gujarat. Rajasthan claims the monopoly in production accounting for about $80-90 \%$ of fenugreek produce in the country. The seeds are used as spices and condiment to improve the flavour and nutritive value of food. Being due to its mucilaginous, demulcent diuretic, carminative, astringent and aphrodisiac properties of seeds are also used in preparation of several ayurvedic medicines. Seed contains diosgenin which is used in the preparation of contraceptive pills. In any crop breeding programme, germplasm serve as the most valuable reservoir in providing variability for various traits. Proper screening and evaluation of germplasm lines would provide an estimate about their potential value as suitable genotype for utilization in varietal development programme. Selection and hybridization approaches are easily followed in bringing about the quantitative improvement in order to bring about desired improvement. Beside knowledge of inter-character association and direct and indirect effect on seed yield is also essential. Yield is the end product of various characters, which directly or indirectly influence the growth of plant. The correlation coefficient gives an idea about the various associations existing between yield and yield components. It only reveals the direction and magnitude of association between any two characters but the path-coefficient analysis helps in partitioning the correlation into direct and indirect effects of various components on yield.
Corresponding Author: VP Pandey

Professor, Department of Vegetable Science, College of Horticulture and Forestry, Narendra Deva University of Agriculture and Technology, Kumarganj, Faizabad, Ayodhya, Uttar Pradesh, India 
Emphasized the theory of path coefficient for statistical analysis of causes and effects, which give critical examinations of specific forces to produce a correlation. Therefore, correlation studies along with path coefficient analysis serve as a powerful tool to study the character association and their final impact on yield which helps in the selection procedure accordingly.

\section{Materials and Methods}

The experimental material consisted of 122 genotypes Narendra Methi (NDM-1) to Narendra Methi (NDM-120) including two check varieties Pusa Early Bunching (PEB) IARI, New Delhi and Hisar Sonali (C.C.S.H.A.U., Hisar, Haryana) was carried out during Rabi season of the year 2014-15 at Main Experiment Station of Department of Vegetable Science (Vegetable Research Farm) at Narendra Deva University of Agriculture and Technology, Narendra Nagar (Kumarganj), Faizabad (Ayodhya) Uttar Pradesh, India. Geographically the experimental site falls under humid subtropical climate and it is located at $26^{\circ} 47^{\prime} \mathrm{N}$ latitude and $82^{\circ} 12^{\prime}$ E longitudes at an elevation of altitude of 113 meter above the mean sea level. It falls in north east gangetic alluvial plains of eastern U.P. Faizabad region. The experiment was laid out in Augmented Block Design with three replications individual plot size $(2 \mathrm{~m} \times 1.2 \mathrm{~m})$. The distance maintained between row to row and plant to plant (30 $\mathrm{cm} \times 10 \mathrm{~cm}$ ). The field had sandy loam soil, low in organic carbon and slightly alkaline in nature $(\mathrm{pH}$ 8.0). All recommended agronomic practices for the region were adopted to raise healthy crops. Five plants were selected randomly from each plot to record. For the data observation 10 characters were considered viz., days to $50 \%$ flowering, days to maturity, plant height $(\mathrm{cm})$, branches per plant, pods per plant, length of pod $(\mathrm{cm})$, seeds per pod, 1000-seed weight $(\mathrm{g})$, seed yield per plant $(\mathrm{g})$ and seed yield $(\mathrm{q} / \mathrm{ha})$.

\section{Results and Discussion \\ Correlation coefficient}

A perusal of data in Table No. 1 Seeds yield per plant showed that positive and highly significant correaltion with pods per plant $\left(0.7821,07679^{* *}\right)$ followed by length of pod $(0.1529$, $0.1517)$, days to maturity $(0.0285,0.0149)$ whereas it showed highly negative correlation significant seeds per pod (-0.3051) followed by 1000 -seed weight $(-0.2950)$ at genotypic and 1000 -seed weight $(-0.2948 *)$ followed by days to $50 \%$ flowering (-0.1059) at phenotypic correlation coefficient.

Days to $50 \%$ flowering showed significant and positive correlation with days to maturity $(0.2968)$ followed by days to maturity $(0.1638,0.0494)$, plant height $(0.0792,0.0457)$ and branches per plant $(0.1391 *)$ at genotypic and phenotyipc correlation. Days to maturity showed positive correlation and significant with seeds per pod $(0.1053)$ followed by branches per plant $(0.0332)$, seed yield per plant $(0.0285)$ and 1000 seed weight $(0.0618)$ followed by pods per plant $(0.0610)$, length of pods (0.0530) at genotypic and phenotyipc correlation level. The genotypic and phenotyipc correlation association of plant height showed significant and positive correlation with seeds per pod $\left(0.1091,0.1105^{*}\right)$. Branches per plant showed significant and positive correlation with 1000 seed weight $\left(0.1313,0.1253^{*}\right)$ followed by pods per plant $(0.0139,0.0155)$ at genotypic and phenotyipc correlation respectively. The genotypic and phenotyipc correlation association of pods per plant showed significant and positive correlation with seeds yield per plant $(0.7821,0.7679)$ and length of pod $\left(0.1415,0.1308^{*}\right)$. Length of pods showed positive correlation and significant with seeds yield per plant $(0.1529,0.1517)$ followed by 1000 -seed weight $(0.0952$, 0.927 ) at genotypic and phenotyipc correlation level. Some of these characters have also been reported to exhibited positive correlation with seed yield by earlier workers Shukla and Sharma (1978) ${ }^{[11]}$; Singh and Raghuvansi (1984) ${ }^{\text {[12]; Dash }}$ and Kole (2000) ${ }^{[1]}$; Kole and Mishra (2006) [5]; Gangopadhyay et al. (2009) ${ }^{[4]}$.

\section{Path analysis}

The path coefficient analysis was carried out by using genotypic as well phenotypic correlation coefficient between nine characters to estimate direct and indirect effects of eight characters on seeds yield per plant. The direct and indirect effects of different characters on seeds yield per plant at genotypic and phenotypic level are presented in Table No 2. The highest positive direct effect seeds yield per plant on was exerted by pods per plant $(0.7193,0.7322)$ followed by length of pod $(0.0573,0.0376)$ and highly negative direct effect seed yield per plant on 1000 -seed weight $(-0.1194)$ followed by plant height $(-0.0633)$, days to $50 \%$ flowering $(-0.0494)$ and branches per plant $(-0.0354)$. The direct effects of remaining characters are too low to be considered important. Seeds per pod $(-0.0265,0.0045)$, followed by 1000 -seed weight $(0.0007$, $0.0061),(-0.0019,0.0036)$ exhibited highest positive indirect effect on seed yield per plant. The rest of estimates of indirect effects obtained in path coefficient analysis at phenotypic level are negligible. The estimates of residual factor $(0.6201$, $0.6034)$ obtained in this phenotypic and genotypic path analysis are low. These characters have also been identified as major direct contributors towards seed yield in different crops by earlier workers, Pant et al. (1984) ${ }^{[8]}$; Singh and Raghuvanshi (1984) ${ }^{[12]}$; Singh et al. (1987) ${ }^{[10]}$; Khattab et al. (1991) ${ }^{[7]}$; Kailash Chandra (1992) ${ }^{[6]}$; Dash and Kole (2000) [1]; Datta et al. (2005) ${ }^{[2]}$; Dashora et al. (2011) ${ }^{[3]}$; Patahk et al. (2014) ${ }^{[9]}$. The direct effects of remaining characters were negligible phenotypic and genotypic path analysis.

Table 1: Estimates of genotypic and phenotypic correlation coefficients between different Charcters in fenugreek germplasm

\begin{tabular}{|c|c|c|c|c|c|c|c|c|c|c|}
\hline \multirow[t]{2}{*}{ S. No. } & \multirow[t]{2}{*}{ Characters } & & $\begin{array}{c}\text { Days to } \\
\text { maturity }\end{array}$ & $\begin{array}{c}\text { Plant } \\
\text { Height }(\mathrm{cm})\end{array}$ & $\begin{array}{l}\text { Branches } \\
\text { Per plant }\end{array}$ & $\begin{array}{c}\text { Pods } \\
\text { Per plant }\end{array}$ & $\begin{array}{c}\text { Length } \\
\text { of } \operatorname{pod}(\mathrm{cm})\end{array}$ & $\begin{array}{c}\text { Seeds per } \\
\text { pod }\end{array}$ & $\begin{array}{c}1000 \text { - seed } \\
\text { weight }\end{array}$ & $\begin{array}{c}\text { Seed yield } \\
\text { plant }^{1}(\mathrm{~g})\end{array}$ \\
\hline & & & 1 & 2 & 3 & 4 & 5 & 6 & 7 & 8 \\
\hline \multirow{2}{*}{1} & \multirow{2}{*}{$\begin{array}{c}\text { Days to } 50 \% \\
\text { flowering }\end{array}$} & $\mathrm{g}$ & 0.2968 & 0.0792 & 0.1638 & -0.1075 & -0.0875 & -0.0410 & -0.0336 & -0.1272 \\
\hline & & $\mathrm{p}$ & 0.0494 & 0.0457 & $0.1391 *$ & -0.0581 & -0.0129 & 0.0099 & 0.0385 & -0.1059 \\
\hline \multirow{2}{*}{2} & \multirow{2}{*}{$\begin{array}{l}\text { Days to } \\
\text { maturity }\end{array}$} & $\mathrm{g}$ & & -0.1984 & 0.0332 & 0.0085 & 0.0201 & 0.1053 & -0.1551 & -0.0285 \\
\hline & & $\mathrm{p}$ & & -0.0586 & 0.0233 & 0.0610 & 0.0530 & $-0.1240 *$ & 0.0618 & 0.0149 \\
\hline \multirow{2}{*}{3} & \multirow{2}{*}{$\begin{array}{l}\text { Plant height } \\
\text { (cm) }\end{array}$} & $\mathrm{g}$ & & & -0.0950 & -0.0059 & -0.1719 & 0.1091 & -0.0715 & -0.0912 \\
\hline & & $\mathrm{p}$ & & & -0.0921 & -0.0242 & $-0.1492 *$ & $0.1105^{*}$ & -0.0665 & -0.0815 \\
\hline \multirow[b]{2}{*}{4} & \multirow{2}{*}{$\begin{array}{c}\text { Branches per } \\
\text { plant }\end{array}$} & $\mathrm{g}$ & & & & 0.0139 & -0.0290 & -0.0029 & 0.1313 & -0.0476 \\
\hline & & $\mathrm{p}$ & & & & 0.0155 & -0.0263 & -0.0010 & $0.1253^{*}$ & -0.0424 \\
\hline 5 & Pods per plant & $\mathrm{g}$ & & & & & 0.1414 & -0.3636 & -0.2588 & 0.7821 \\
\hline
\end{tabular}




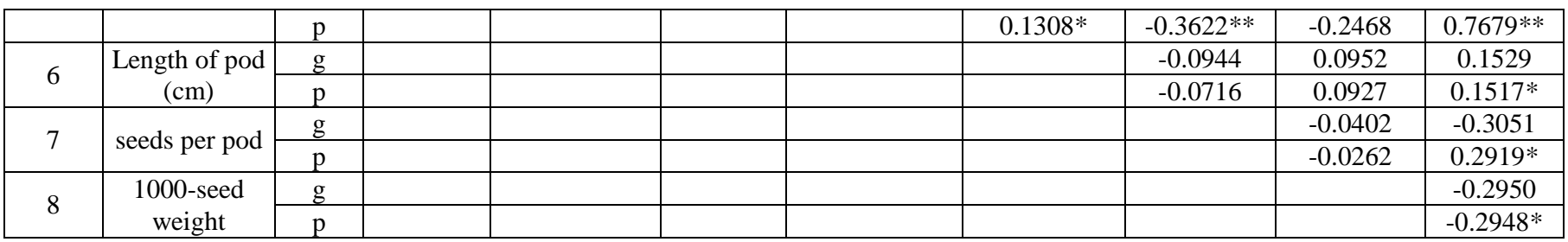

Table 2: Direct and indirect effects of different on seed yield per plant at genotypic and phenotypic level in fenugreek germplasm

\begin{tabular}{|c|c|c|c|c|c|c|c|c|c|c|c|}
\hline \multirow[t]{2}{*}{ S. No. } & \multirow[t]{2}{*}{ Characters } & & $\begin{array}{c}\text { Days to 50\% } \\
\text { flowering }\end{array}$ & $\begin{array}{c}\text { Days to } \\
\text { maturity }\end{array}$ & $\begin{array}{c}\text { Plant } \\
\text { Height }(\mathrm{cm})\end{array}$ & $\begin{array}{l}\text { Branches } \\
\text { per plant }\end{array}$ & \begin{tabular}{|c|} 
Pods \\
per plant
\end{tabular} & $\begin{array}{l}\text { Length of } \\
\operatorname{pod}(\mathrm{cm})\end{array}$ & \begin{tabular}{|c|} 
seeds \\
per pod
\end{tabular} & \begin{tabular}{|c|}
$1000-$ \\
seed weight
\end{tabular} & $\begin{array}{c}\text { Correlation with Seed } \\
\text { yield plant }{ }^{-1}(\mathrm{~g})\end{array}$ \\
\hline & & & 1 & 2 & 3 & 4 & 5 & 6 & 7 & 8 & 9 \\
\hline \multirow{2}{*}{1} & \multirow{2}{*}{$\begin{array}{c}\text { Days to } 50 \% \\
\text { flowering }\end{array}$} & $\mathrm{g}$ & -0.0372 & 0.0010 & -0.0068 & -0.0072 & -0.0787 & -0.0033 & 0.0013 & 0.0037 & -0.01272 \\
\hline & & $\mathrm{p}$ & -0.0494 & -0.0014 & -0.0029 & -0.0049 & -0.0418 & -0.0007 & -0.0003 & -0.0046 & -0.1059 \\
\hline \multirow{2}{*}{2} & \multirow{2}{*}{$\begin{array}{l}\text { Days to } \\
\text { maturity }\end{array}$} & $\mathrm{g}$ & -0.0110 & 0.0032 & 0.0017 & -0.0015 & 0.0062 & 0.0008 & -0.0034 & 0.0173 & 0.0285 \\
\hline & & $\mathrm{p}$ & -0.0024 & -0.0284 & 0.0037 & -0.0008 & 0.0439 & 0.0030 & 0.0033 & -0.0074 & 0.0149 \\
\hline \multirow{2}{*}{3} & \multirow{2}{*}{$\begin{array}{c}\text { Plant height } \\
(\mathrm{cm})\end{array}$} & $\mathrm{g}$ & -0.0029 & -0.0006 & -0.0854 & 0.0042 & -0.0043 & -0.0065 & \begin{tabular}{|l|}
-0.0036 \\
\end{tabular} & 0.0080 & -0.0912 \\
\hline & & $\mathrm{p}$ & -0.0023 & 0.0017 & -0.0633 & 0.0033 & 0.0174 & -0.0085 & -0.0029 & 0.0079 & -0.0815 \\
\hline \multirow{2}{*}{4} & \multirow{2}{*}{$\begin{array}{c}\text { Branches per } \\
\text { plant }\end{array}$} & $\mathrm{g}$ & -0.0061 & 0.0001 & 0.0081 & -0.0443 & 0.0102 & -0.0011 & 0.0001 & -0.0146 & -0.0476 \\
\hline & & $\mathrm{p}$ & -0.0069 & 0.0007 & 0.0058 & 0.0354 & 0.0112 & -0.0015 & 0.0000 & -0.0150 & -0.0424 \\
\hline \multirow{2}{*}{5} & \multirow{2}{*}{$\begin{array}{c}\text { Pods per } \\
\text { plant }\end{array}$} & $\mathrm{g}$ & 0.0040 & 0.0000 & 0.0005 & -0.0006 & 0.07322 & 0.0053 & 0.0118 & 0.0288 & 0.7821 \\
\hline & & $\mathrm{p}$ & 0.0029 & -0.0017 & 0.0015 & -0.0005 & 0.7193 & 0.0075 & \begin{tabular}{|l|}
0.0096 \\
\end{tabular} & 0.0295 & 0.7679 \\
\hline \multirow{2}{*}{6} & \multirow{2}{*}{$\begin{array}{l}\text { Length of } \\
\text { pod }(\mathrm{cm})\end{array}$} & $\mathrm{g}$ & 0.0033 & 0.0001 & 0.0147 & 0.0013 & 0.1036 & 0.0376 & -0.0106 & 0.0036 & 0.1529 \\
\hline & & $\mathrm{p}$ & 0.0006 & -0.0015 & 0.0094 & 0.0009 & 0.0941 & 0.0573 & 0.0019 & -0.0111 & 0.01517 \\
\hline \multirow[b]{2}{*}{7} & \multirow{2}{*}{ seeds per pod } & $\mathrm{g}$ & 0.0015 & 0.0003 & -0.0093 & 0.0001 & -0.2662 & -0.0035 & -0.0325 & 0.0045 & -0.03051 \\
\hline & & $\mathrm{p}$ & -0.0005 & 0.0035 & -0.0070 & 0.0000 & -0.2605 & -0.0041 & -0.0265 & 0.0031 & -0.2919 \\
\hline \multirow[b]{2}{*}{$\varepsilon$} & \multirow{2}{*}{$\begin{array}{c}\text { 1000-seed } \\
\text { weight }\end{array}$} & $\mathrm{g}$ & 0.0012 & -0.0005 & 0.0061 & -0.0058 & -0.1895 & 0.0036 & 0.0013 & -0.1114 & -0.2950 \\
\hline & & $\mathrm{p}$ & -0.0019 & 0.0018 & 0.0042 & -0.0044 & -0.1775 & -0.0053 & 0.0007 & -0.1194 & -0.2948 \\
\hline
\end{tabular}

\section{Conclusion}

Based on overall findings of the present study, it was concluded that there was a wide range of variation among the germplasm lines for all the characters indicating that considerable scope existed for the improvement of fenugreek cultivars through selections. Genetic parameters in association with correlation study indicated that for selection of superior genotypes primary, emphasis should be given on number of pods per plant, number of seeds per pod and length of pod. Out of one hundred twenty genotypes and two checks, NDM39, NDM-49, NDM-17, NDM-45, NDM-38, NDM- 11, NDM-48, NDM-18, NDM-14, NDM-25 and NDM-2 were found superior for yield and these germplasm may be recommended for large scale cultivation among the farmers after proper testing in multilocational trials and these superior genotypes can be used as donors in breeding programme.

\section{References}

1. Dash SR, Kole PC. Association analysis of seed yield and its components in fenugreek (Trigonella foenum-graecum L.). Crop Res 2000;20:449-452.

2. Datta S, Chaterjee R, Mukherjee S. Variability, heritability and path analysis studies in fenugreek (Trigonella foenum-graecum L.). Indian J Hort 2005;62(1):96-98.

3. Dashora A, Maloo SR, Dashora LK. Variability, correlation and path coefficient analysis in fenugreek (Trigonella foenum-graecum L.) under water limited conditions. Journal of Spices and Aromatic Crops 2011;20(1):38-42.

4. Gangopadhyay KK, Yadav SK, Meena, Gunjeet Kumar, Mahajan BL, Mishra RK et al. Correlation and path coefficient and genetic diversity pattern in fenugreek (Trigonella foenum-graecum L.). Indian J agric. Sci 2009;79(7):521-526.

5. Kole PC, Mishra AK. Pattern of variability and association among quantitative characters in fenugreek
(Trigonella foenum-graecum L.). Indian Agril 2006;50(3/4):93-96.

6. Kailash, Chandra. Genetic variation and association among yield and yield related characters in fenugreek (Trigonella foenum-graecum L.), M.Sc. (Ag.), Thesis Rajasthan Agricultural University, Bikaner (unpublished) 1992.

7. Khattab AM, El-Attar AN, Rebeia BMB. Correlation studies both analysis and its implication in fenugreek, breeding. Bull. Eae. Agri. Univ. Cario 1991;42(3):981992.

8. Pant KC, Chandel KPS, Pant DC. Variability and path coefficient in fenugreek (Trigonella foenum-graecum L.). Indian J agric. Sci 1984;54:655-658.

9. Patahk AR, Patel AI, Joshi HK, Patel DA. Genetic variability, correlation and path coefficient analysis in fenugreek (Trigonella foenum-graecum L.). Trends in Biosciences 2014.

10. Singh SP, Santoshi US, Singh KN, Singh IB. Path coefficient study in segregating generations. Legume Res 1987;10:95-96.

11. Shukla GP, Sharma RK. Genetic variability correlation and path analysis in fenugreek (Trigonella foenumgraecum L.). Indian J agric. Sci 1978;48:518-521.

12. Singh RR, Raghuvansi SS. Correlation and path coefficient analysis in fenugreek (Trigonella foenumgraecum L.). Indian J Hort 1984;41:294-298. 